\title{
UPAYA MENGOPTIMALKAN GERAKAN LITERASI PADA IKATAN PELAJAR MUHAMMADIYAH KABUPATEN BANYUMAS
}

\author{
Makhrus $^{1}$ dan Putri Dwi Cahyani ${ }^{2}$ \\ ${ }^{1}$ Universitas Muhammadiyah Purwokerto \\ ${ }^{2}$ Universitas Muhammadiyah Purwokerto
}

\begin{abstract}
ABSTRAK
Kegiatan pelatihan penulisan kreatif kreatif dan publikasi dalam upaya mengoptimalkan gerakan literasi pada Pimpinan Daerah Ikatan Mahasiswa Muhammadiyah Kabupaten Banyumas bertujuan memberikan dorongan motivasi kepada pada kader dan pimpinan mengenai pentingnya optimalisasi dan kesadaran mengenai gerakan literasi, memberikan pemahaman dan wawasan yang komprehensif mengenai hal-hal yang berkaitan dengan penulisan kreatif dan publikasi, memberikan keterampilan/skill tentang penulisan kreatif dan publikasi.

Program pelatihan ini diberikan kepada kader dan pimpinan Dewan Pimpinan Ikatan Pelajar Muhammadiyah Kabupaten Banyumas dengan menggunakan metode seminar, diskusi dan sharing. Harapan kegiatan ini agar para peserta dapat memahami, mengerti, dan mampu mempraktikkan menulis kreatif dalam berbagai bentuk tulisan yang peserta hasilkan, sehingga dapat memberikan dalam positif terhadap perkembangan organisasi melalui gerakan literasi.

Adanya pelatihan pelatihan penulisan kreatif dalam upaya mengoptimalkan gerakan literasi pada Pimpinan Daerah Ikatan Mahasiswa Muhammadiyah Kabupaten Banyumas memiliki dampak penambahan wawasan mengenai teknik penulisan kreatif, hal tersebut dapat terlihat dari keinginan para kader dan untuk mempublikasikan tulisan dalam bentuk buku dan mengoptimalkan media sosial yang dimiliki sebagai sarana formal organisasi. Secara internal gerakan PD IPM Kabupaten Banyumas sudah memiliki tradisi keilmuan dan budaya literasi yang baik, hal tersebut dipengaruhi oleh corak dan kultur keilmuan gerakan IPM secara nasional yang sangat mendorong gerakan literasi di kalangan pelajar. Berdasarkan hasil evaluasi para peserta menyatakan puas dan berharap agar tindak lanjut kegiatan dalam beragam kegiatan formal dan khusus yang dilaksanakan oleh PD IPM Kabupaten Banyumas.
\end{abstract}

Kata-kata kuci : penulisan, publikasi, kreatif, literasi. 


\section{ABSTRACT \\ EFFORTS TO OPTIMIZE MOVEMENT IN LITERACY FOR REGIONAL EXECUTIVE OF MUHAMMADIYAH STUDENTS ASSOCIATION BANYUMAS}

The training activities of creative writing creative and publications in an effort to optimize the literacy movements in the Regional Executive of Muhammadiyah Students Association Banyumas aimed at providing encouragement to the cadres and leaders of the importance of optimization and awareness of literacy movements, provide insight and comprehensive insight on matters relating with creative writing and publications, providing skills on creative writing and publication.

The training program is given to the cadres and leaders of Muhammadiyah Student Association Executive Board Banyumas using methods seminar, discussion and sharing. Hope this activity to get participants to understand, understand, and be capable of practicing creative writing in various forms of writing that participants produce, so as to provide the positive to the organization's development through literacy movement.

Training in creative writing in an effort to optimize the literacy movements in the Regional Executive of Muhammadiyah Students Association Banyumas have the effect of adding insight into the techniques of creative writing, it can be seen from the desire of cadres and to publish writings in book form and optimize social media held as a means of formal organization. Internally movement PD IPM Banyumas already has a tradition of scientific and cultural literacy are good, it is influenced by the style and culture of the national scientific IPM movement which strongly encourages literacy movement among students. Based on the evaluation of the participants expressed satisfaction and hope that the follow-up activities in a variety of formal and specific activities implemented by PD IPM Banyumas.

Keywords: writing, publishing, creative, literacy. 


\section{PENDAHULUAN}

Kehidupan manusia tidak bisa terlepaskan dari kehidupan tradisi membaca dan menulis, setidaknya hal ini didasarkan pada saat manusia mengenal tulisan beberapa abad yang yang lalu, sekalipun dalam bentuk kode dan sandi. Namun, upaya menusia mengenal tulisan tersebut juga diimbangi dengan keinginan untuk bisa membaca agar dapat memudahkan manusia mengenal, mengetahui dan memecahkan berbagai kode dan sandi yang menjadi kesepakatan manusia manusia pada saat itu. Seiring perkembangan kehidupan dan pengetahuan manusia lambat laun tradisi membaca dan menulis (literasi) menjadi hal yang tidak bisa dipisahkan, sebab pola interaksi manusia yang satu dengan yang lain tidak bisa hanya dilakukan dengan bentuk interaksi isyarat dan berkomunikasi, melainkan juga dengan bentuk tulisan. Manusia dapat mengetahui generasi pendahulu, pesan, dan warisan tertentu bisa diketahui dengan tradisi dan warisan literasi yang ditinggalnya.

Adanya gerakan literasi sebagai kemampuan membaca dan menulis, sehingga dalam perspektif kebudayaan budaya literasi bertujuan untuk melakukan kebiasaan berpikir yang diikuti dengan proses membaca, menulis, dan akhirnya diikuti dengan kegiatan berkarya (Haryanti, 30/3). Seiring berjalannya waktu, tingkat pengetahuan, dan corak kehidupan manusia semakin bertambah, budaya literasi manusia juga semakin berkembang. Berbagai bentuk karya manusia mampu dihasilkan dalam bentuk dan cara yang juga beragam. Kini, perkembangan dunia literasi ternyata juga diimbangi dengan perkembangan media sosial yang bisa menjadi wadah baru dalam mempublikasikan berbagai tulisan, sehingga menyebabkan wabah baru dalam dunia penulisan yang kemudian disebut menulis kreatif yakni menulis dengan memanfaatkan semua media untuk mengeksplor secara lebih jauh kegiatan menulis. Termasuk, hal tersebut juga diimbangan dengan pemikiran kreatif khas pelajar atau kaum muda (Makhrus, 2017:44). Jadi, perkembangan dunia digital dan media sosial juga memberikan pengaruh yang cukup besar terhadap keberadaaan dan perkembangan gerakan literasi yakni dengan adanya ebook, e-jurnal, e-majalah, e-koran, dan lainnya.

Secara global peningkatan dunia literasi ditunjukkan dengan semakin banyaknya buku yang dipublikasikan. Hal ini sekaligus memberikan pertanda bahwa semakin banyak buku yang dipublikasikan, maka semakin besar pula kesadaran literasinya. Berdasarkan laporan International Publisher Assaciaton (IPA) merangkan bahwa Inggris merupakan negara yang paling banyak menerbitkan buku, pada tahun 2013 saja terdapat 184 ribu judul buku baru dan 


\section{Islãmadîna \\ JURNAL PEMIKIRAN ISLAM}

revisi yang meningkat pada tahun 2014 menjadi 20 judul buku yang terbit setiap jamnya. Sementara posisi berikutnya disusul oleh Taiwan dan Slovakia dengan 1.831 judul per satu juta penduduk (liputan6.com 30/3). Tentu saja, posisi Indonesia masih berada dibawah ketiga negara tersebut, hal ini ditandai dengan masih adanya tingkat buta aksara di Indonesia yang mencapai enam persen dari total penduduk (republika.co.id, 30/3), sekalipun, jumlah buta akra aksara tersebut merupakan penduduka yang sudah berusia 44 tahun keatas.

Mendorong gerakan literasi di Indonesia harus dilakukan secara kolektif setiap lapisan masyarakat tanpa terkecuali. Apalagi, dalam membentuk budaya literasi dapat dilakukan dengan beragam cara, salahnya dengan melakukan pendekatan akses dengan menyediakan fasilitas dan beragam buku bacaan, memudahkan akses dengan memberikan kemudahan dalam menyediakan bahan bacaan, dan dilakukan secara berkesinambungan yang pada akhirnya menyebabkan timbulnya tradisi berliterasi yang kuat di masyarakat.

Adanya gerakan literasi ini banyak dikampanyekan oleh orang perseorangan, taman/rumah baca, organisasi, dan komunitas literasi yang didalamnya termasuk Ikatan Pelajar Muhammadiyah (IPM) harus mendapatkan apresiasi oleh semua pihak. Dalam konteks IPM keberadaan gerakan literasi termasuk dalam bentuk nilai gerakan, sebab dalam semboyan IPM sangat terinspirasi dengan QS. Nuun: 1-2 yakni “nuun wal qalami wa maa yasturun”. Maka, secara padigmatik dunia dan gerakan literasi menjadi hal yang tidak terpisahkan dari gerakan dan aktivisme IPM secara kolektif, tidak terkecuali pada Pimpinan Daerah Ikatan Pelajar Muhammadiyah (PD IPM) Kabupaten Banyumas. Sementara ini, yang dilakukan oleh PD IPM Kabupaten Banyumas dalam mendorong budaya literasi secara internal kader dan pimpinan dengan memaksimalkan perpustakaan mini yang dimiliki oleh PD IPM Kabupaten Banyumas itu sendiri.

Bentuk gerakan literasi yang dilakukan secara kolektif oleh PD IPM Kabupaten Banyumas dengan melakukan training menulis, memaksimalkan fungsi blog dan media sosial yang dimiliki, sehingga dengan adanya sharing tulisan melalui media sosial PD IPM Kabupaten Banyumas, mampu menerbitkan buku yang merupakan hasil tulisan dari pada kader dan pimpinan PD IPM Kabupaten Banyumas itu sendiri. Selain itu, bentuk ekspositas gerakan kreatif yang dilakukan oleh IPM Kabupaten Banyumas tersebut dapat dilakukan dengan memaksimalkan keberadaan media sosial yang kini menjadi hal yang tidak terpisahkan dengan pelajar (kaum muda), sehingga pada akhirnya, akan 
memberikan dampak positif serta mampu menginspirasi dan dipraktikkan di tempat lain, sekalipun dengan pola dan gerakan yang berbeda terutama dikalangan kaum muda (pelajar).

Bentuk gerakan literasi lainnya yang dilakukan oleh PD IPM Kabupaten Banyumas yakni dengan memaksimalkan peran Maos Corner yang merupakan perpustakaan mini milik PD IPM Kabupaten Banyumas. Keberadaan Maos Corner mampu menyediakan beberapa sumber bacaan yang berasal donasi buku kader dan berbagai pihak yang memiliki visi yang sama dalam mendorong budaya membaca literasi pelajar dan masyarakat. Selain itu, keberadaan Maos Corner juga melakukan jemput pembaca dengan membuka lapak bacaan di tempat strategis yang memungkinkan masyarakat bisa membaca buku yang telah disediakan oleh Maos Corner, sehingga proses penyadaran tentang pentingnya budaya literasi menjadi lebih efektif dikarenakan dilakukan dengan cara jemput bola. Pola gerakan literasi yang dilakukan oleh Maos Corner PD IPM Kabupaten Banyumas hampir sama dengan yang dilakukan oleh Rumah Baca Komunitas (RBK) di Yogyakarta, sebab keberadan RBK sendiri terlahir dari para mantan aktivis IPM di Yogyakarta yang secara kultur emosional dan struktural sangat terkait dengan PD IPM Kabupaten Banyumas.

Upaya mendorong gerakan literasi di PD IPM Kabupaten Banyumas ini agaknya akan mendapat dukungan positif secara kelembagaan. Sebab, hingga saat ini PD IPM Kabupaten Banyumas telah memiliki 11 Pimpinan Cabang yang membawahi Pimpinan Ranting IPM yang berada di sekolah-sekolah Muhammadiyah di Kabupaten Banyumas. Namun, hal ini dapat terwujud secara maksimal manakala mendapatkan banyak dukung dari semua stakeholders yang memiliki visi yang sama dalam gerakan literasi. Berdasarkan alasan diatas, maka kami berkeinginan untuk melakukan IPTEK bagi Masyarakat (IbM) dengan mengambil judul pengabdian "Upaya Mengoptimalkan Gerakan Literasi pada Ikatan Pelajar Muhammadiyah Kabupaten Banyumas"

\section{METODE PENGABDIAN PADA MASYARAKAT}

Solusi yang ditawarkan dalam kegiatan upaya mengoptimalkan gerakan literasi pada Pimpinan Daerah Ikatan Pelajar Muhammadiyah (PD IPM) Kabupaten Banyumas adalah pelatihan penulisan kreatif dan publikasi. Pemilihan pelatihan dalam kegiatan ini diharapakan agar pemahaman peserta terkait berbagai hal lebih maksimal, selain itu, adanya pelatihan ini merupakan follow up pelaksanaan pengabdian masyarakat yang pernah dilaksanakan oleh anggota tim pelaksana yang berjudul "Pelatihan Creative Writhink pada Ikatan Pelajar 


\section{Islãmadîna \\ JURNAL PEMIKIRAN ISLAM}

Muhammadiyah Kabupaten Banyumas" pada tahun 2015/2016. Pemilihan mitra yang sama dalam rencana pelaksanaan kegiatan pengabdian ini agar efek dari pengabdian yang bersifat jangka panjang mampu memberikan dampak positif yang signifikan tehadap semua peserta dan pihak mitra, selain itu pihak mitra beranggapan bahwa proses pelaksanan sebelumnya masih membutuhkan follow up dan pendampingan dari tim pelaksana.

Metode atau pendekatan yang hendak digunakan dalam proses kegiatan upaya mengoptimalkan gerakan literasi ini adalah memberikan pemahaman dan wawasan komprehensif mengenai penulisan kreatif dan publikasi dengan mengedepankan 3 (tiga) materi yakni teknik penulisan fiksi, teknik penulisan non-fiksi, dan teknik publikasi. Ketiga materi tersebut disampaikan kepada peserta pada pelaksanaan pelatihan, hal tersebut diluar pertemuan atau jadual kerja dengan pihak mitra pelaksana untuk menentukan format pelatihan yang tepat untuk diterapkan, sehingga output yang dihasilkan dapat maksimal. Berkaitan pemilihan ketiga materi pelatihan tersebut diatas, tim pelaksana memberikan term of reference (ToR) dengan sub pokok materi, diantaranya: pertama, materi teknik penulisan fiksi diarahkan menjelaskan terkait pengertian tulisan fiksi, macam dan bentuk tulisan fiksi, cara membuat tulisan fiksi, contoh karya fenominal tulisan fiksi dan lainnya. Kedua, teknik penulisan non-fiksi, pada materi ini pemateri diarahkan untuk menjelaskan mengenai pengertian tulisan non-fiksi, macam dan bentuk tulisan non-fiksi, cara membuat tulisan non-fiksi, dan contoh tulisan non-fiksi. Ketiga, teknik publikasi tulisan yang mengarahkan pemateri untuk menjelaskan mengenai cara kreatif menerbitkan buku, kiat sukses menerbitkan buku pada penerbit mayor dan minor (indie), proses menerbitkan buku, dan lainnya.

Pemahaman dan kesadaran mengenai gerakan literasi tersebut diatas dilakukan dengan memberikan materi yang terbagi pada masing-masing sesi materi dengan metode parsipatoris dialogis. Pada tiap pelaksanaan penyampaian materi oleh pemateri, para peserta diberikan kesempatan tanya jawab untuk bisa sharing dengan pemateri terkait materi yang disampaikan, sehingga terjadi dialog antara pemateri dengan peserta. Adapun kegiatan ini memiliki langkah-langkah sebagai berikut : Pertama, emberian materi dilakukan dengan pemaparan materi oleh pemateri sesuai dengan ToR yang telah tim pelaksana dan mitra tentukan sebelumnya. Materi tersebut disampaikan secara ceramah, sehingga pemahaman dan wawasan para peserta mengenai penulisan kreatif dan publikasi dapat bertambah. Kedua, proses upaya mengoptimalkan gerakan literasi dilakukan dengan memberikan himbauan agar membawa naskah buku 
yang telah siap diterbitkan. Selanjutnya, pada saat sesi tanya jawab dimasing-masing materi, pemateri memberikan review terhadap tulisan para peserta tersebut, namun sebelumnya tim pelaksana dan mitra pelaksana telah mengkatagorikan tulisan peserta tersebut sesuai dengan materi. Dari hasil review tersebut, para peserta dapat memperbaiki tulisannya sehingga menjadi bahan publikasi yang siap dipublikasikan dalam bentuk buku ontologi maupun dikirim ke media massa. Ketiga, praktik, teknik dan pembuatan tulisan kreatif dan publikasi disampaikan secara menarik oleh semua pemateri (narasumber), sehingga memudahkan peserta menangkap isi berbagai isi materi dan review yang disampaikan oleh pemateri. Keempat, praktik dilakukan secara serentak terhadap semua peserta berkaitan dengan masing-masing materi dihadapan peserta lan dengan arahan dan bimbingan dari para pemateri (nasumber).

Berkaitan dengan keterampilan/skill para peserta dalam mengoptimalkan gerakan literasi melalui pelatihan penulisan kreatif dan publikasi, para peserta juga diberikan kesempatan untuk mempresentasikan secara singkat mengenai bentuk tulisan yang telah disediakan sebelumnya oleh peserta sendiri, sehingga terjadi dialog antara sesama peserta dan pemateri yang kemudian memberikan review terhadap tulisan peserta tersebut. Artinya, penilaian skill peserta tidak saja datang dari pemateri saja, melainkan juga dari sesama peserta, sehingga para peserta mendapatkan saran kontruktif untuk bekal berkarya di masa depan.

Adapun bentuk partisipasi mitra dalam kegiatan pelatihan termanifestasi dalam berikut ini: pertama, perencanaan, pada proses perencanaan tim pelaksana bersama mitra melakukan koordinasi terkait dengan rencana pelaksanan kegiatan, pemateri, delegasi peserta, tempat pelaksanaan, materi, dan target selama proses pelaksanaan kegiatan. Tujuan dalam proses perencanaan tersebut untuk mematangkan pelaksanaan sehingga dapat berjalan secara maksimal. kedua, pelaksanaan. Pada proses pelaksanaan kegiatan pihak mitra diberikan kesempatan seluas-luasnya untuk bisa berperan aktif, baik bertanya, memberikan tanggapan, dan saran. Selain itu, mitra diberikan kesempatan untuk bisa melalukan koordinasi dengan peserta yang notabene merupakan sesama kader dari IPM Kabupaten Banyumas. Ketiga, tahap akhir dari proses kegiatan ini adalah evaluasi. Perntingnya adanya evaluasi dari kegiatan workshop yang dilaksanakan mengacu kepada dua tahap yakni sebelum dan sesudah kegiatan workshop. Bentuk evaluasi sebelum kegiatan workshop kepada seluruh peserta diberikan dalam bentuk pre-test, hal ini bertujuan untuk mengetahui kemampuan para peserta, sehingga dapat digunakan bahan dalam menentukan metode yang tepat bagi para pemateri dan untuk mengetahui input pemahaman 


\section{Islãmadîna \\ JURNAL PEMIKIRAN ISLAM}

peserta saat pra workshop. Sedangkan pada saat selesainya kegiatan workshop peserta diberikan posttest, yang bisa dijadikan bahan evaluasi untuk mengetahui perubahan pemikiran dan pemahaman para peserta pada saat proses berlangsungnya dan selesainya kegiatan workshop.

Jenis luaran yang akan dihasilkan dari kegiatan ini sebagai berikut: pertama, para peserta yang merupakan Pimpinan Daerah IPM Kabupaten Banyumas dan delegasi dari Pimpinan Cabang dan Pimpinan Ranting IPM Kabupaten Banyumas bertambah wawasan dan pemahamannya mengenai gerakan literasi dalam bentuk workshop penulisan kreatif dan publikasi, sehingga dapat menjadi salah satu cara dalam memasifkan gerakan IPM Kabupaten Banyumas dalam berbagai bentuk gerakan, tidak terkecuali menjadi pelopor gerakan dan budaya literasi di Kabupaten Banyumas. Kedua, para kader IPM Kabupaten Banyumas mempunyai kemampuan atau skill dalam penulisan kreatif dan publikasi karya secara baik, sehingga dapat dibuktikan dalam berbagai hasil karya yang dapat dipublikan secara baik dan dinikmati khalayak luas. Ketiga, munculnya para penulis kreatif yang berkualitas, mumpuni dan mampu mencerahkan para pelajar dan masyarakat secara umum, sehingga dapat membanggakan IPM Kabupaten Banyumas dan secara umum persyarikatan Muhammadiyah.

\section{HASIL DAN PEMBAHASAN}

Kegiatan pelatihan penulisan kreatif dan publikasi kepada PD IPM Kabupaten Banyumas dilaksanakan pada hari Sabtu, 3 September 2016 bertempat di Ruang Kuliah Fakultas Sastra Lt. III Universitas Muhammadiyah Purwokerto. Pemilihan tempat kegiatan atas dasar pertimbangan tempat lokasi kegiatan merupakan tempat representatif bagi para peserta, dikarenakan lokasinya yang berada ditengah-tengah daerah Kabupaten Banyumas, serta kemudahan transportasi untuk memudahkan peserta menghadiri kegiatan ini. Selain itu, pertimbangan ketersedaan ruangan kegiatan juga menjadi pertimbangan karena pada saat pelaksanaan kegiatan bertepatan dengan kegiatan Ospek Universitas.

Terkait proses kegiatan, sebelum pelaksanaan kegiatan pelatihan penulisan kreatif dan publikasi dimulai, pihak tim pelaksana dan mitra melakukan pendataan peserta yang merupakan delegasi dari Pimpinan Cabang, Pimpinan Ranting dan pengurus PD IPM Kabupaten Banyumas. Terkait dengan jumlah Pimpinan Cabang PD IPM Kabupaten Banyumas berjumlah 11 Cabang yang membawahi Pimpinan Ranting di Sekolah Muhammadiyah di Kabupaten 
Banyumas, sehingga berdasarkan rapat koordinasi awal dan pendataan jumlah peserta dalam kegiaan ini dibatasi hanya 30 orang hal tersebut bertujuan agar pelaksanaan dan target yang diharapkan selama proses kegiatan mampu memberikan dampak positif terhadap para peserta. Namun dikarenakan berbagai halangan, maka pelatihan penulisan kreatif dan hanya diikuti 20 orang mulai dari materi pertama, kedua, dan ketiga sebagaimana terlampir dalam laporan ini.

Materi kegiatan dalam proses pelaksanaan program ini dilakukan dengan membagi materi dalam tiga sesi agar dapat memberikan manfaat dan dampak yang signifikan terhadap penyelesaikan masalah mitra. Adapaun ketiga sesi materi tersebut yakni: pertama, materi tentang penulisan non-fiksi yang disampaikan oleh Putri Dwi Cahyani, SE., M.EI. yang merupakan dosen Prodi Manajemen UMP. Pemateri menjelaskan mengenai seluk beluk penulisan non fiksi yang harapannya peserta mampu membuat penulisan dan penelitian kreatif sehingga dapat dipublikasikan dalam jurnal ilmiah. Kedua, materi penulisan fiksi yang disampaikan oleh Ratna Dhahita dari Inspirator Akademi Purwokerto, materi ini menjelaskan mengenai bentuk, cara, dan macam penulisan fiksi termasuk diantaranya menghadirkan ide kreatif. Ketiga, materi mempublikasikan secara kreatif yang disampaikan oleh Makhrus, S.EI., M.SI. yang merupakan dosen Prodi Hukum Ekonomi Syariah Universitas Muhammadiyah Purwokerto. Materi disampaikan dengan metode ceramah, kemudian dilanjutkan dengan sesi tanya jawab untuk menyempurnakan pemahaman peserta terkait cara memplikasikan tulisan peserta yang berbentuk tulisan non-fiksi ataupun fiksi.

Gerakan literasi merupakan jendela dunia masa depan, sebab gerakan literasi senantiasa membawa para pegiat dan semua pihak yang terlibat dalam berbagai aktivitas membaca dan menulis. Oleh sebab itu, adanya gerakan literasi harus mendapatkan perhatian dan apresiasi tersendiri oleh semua pihak, hal tersebut dikarenakan gerakan senantiasa mendorong mendorong partisipasi masyarakat dalam beragam aktivitas pengembangan ilmu pengetahuan dan teknologi melalui kebiasaan membaca dan menulis yang pada akhirnya berbagai karya yang dihasilkan mampu memberikan kontribusi positif terhadap kehidupan bermasyarakat dan bernegara.

Upaya mendorong gerakan literasi ditingkat pelajar (anak muda) tentu saja memiliki tantangan tersendiri, apalagi ditengah arus perkembangan teknologi dan informasi yang semakin semakin pesat, sehingga para pegiat dunia literasi dituntut mengakrabkan diri dengan dunia digital untuk menyampaikan beragam 


\section{Islãmadîna \\ JURNAL PEMIKIRAN ISLAM}

informasi dan hasil karyanya yang telah dihasilkan sehingga mudah diakses oleh anak muda yang sangat identik dengan kehidupan dunia digital. Maka, keberadaan Pimpinan Daerah Ikatan Pelajar Muhammadiyah (PD IPM) Kabupaten Banyumas yang terus mendorong gerakan literasi pada kalangan pelajar merupakan salah satu cara untuk memposisikan dunia literasi sebagai investasi jangka panjang yang menyebabkan tingkat tingkat pengetahuan masyarakat semakin baik dan besar.

Adanya pelatihan penulisan kreatif dan publikasi bagi para delegasi kader PD IPM Kabupaten Banyumas merupakan salah satu upaya untuk meningkatkan kesadaran para kader dalam mendorong gerakan literasi pada tiap level pimpinan, kader, dan semua lapisan masyarakat, khsususnya para anak muda di Kabupaten Banyumas. Penyampaian materi dalam kegiatan ini terbagi atas 3 (tiga) sesi materi yakni penulisan non-fiksi, penulisan fiksi, dan publikasi. Ketiga materi tesebut disampaikan kepada peserta pelatihan dengan menggunakan metode ceramah, dimana pemateri menyampakan materi yang telah disediakan sebelumnya, kemudian ditengah sesi materi atau akhir materi para pemateri memberikan kesempatan kepada para peserta untuk menyampaikan pertanyaan, pernyataan, dan ide gagasannya. Selain itu, peserta juga diberikan kesempatan untuk mengekspolasi karya tulisannya yang selanjutnya diberikan komentar maupun review oleh para pemateri, sesuai dengan genre tulisan para peserta, sehingga suasana pelatihan terjadi pola dialog partisipatoris antara pemateri dengan peserta pelatihan.

Materi pertama, mengupas masalah teknis penulisan non-fiksi yang harus dikuasai oleh para peserta, sehingga harapannya para peserta pelatihan mampu membuat beragam tulisan dalam bentuk non fiksi, baik hal tersebut untuk kebutuhan perkaderan, lomba karya tulis ilmiah, maupu penelitian. Timbulnya, kebiasaan menulis non fiksi pada kalangan pelajar pada tahap selanjutnya akan memberikan pengantar tradisi akademik yang baik pada saat peserta yang dalam hal ini kesemuanya merupakan pelajar mampu menyediakan kebutuhan akademik pada saat memasuki dunia kuliah.

Materi kedua dalam pelatihan ini dipaparkan mengenai pentingnya penulisan fiksi. Para peserta diberikan waktu oleh pemateri membuat narasi pendek mengenai satu objek, sehingga para peserta membuat tulisan untuk menjelaskan mengenai objek tersebut menjadi satu rangkaian kalimat yang utuh dan unik. Tujuan utama dari penulisan fiksi ini agar para peserta mampu memanfaatkan kemampuan otak kanan yang penuh dengan ide-ide kreatif sehingga mampu dituangkan dalam bentuk tulisan unik dan kreatif. Selain itu, keberadaan penulisan fiksi secara tidak langsung memberikan ruang kesempatan kepada 
para peserta untuk memasuki alam imajiner yang terbebas dari berbagai tekanan pagu penulisan, sebagaimana terjadi pada penulisan non fiksi.

Sementara materi ketiga dalam kegiatan ini adalah mempublikasikan tulisan secara kreatif yang memfokuskan pada cara peserta mempublikasikan tulisan, baik dalam bentuk jurnal ilmiah, penerbit, dan media digital. Sehingga hasil tulisan yang telah dipersiapkan peserta mengenai tulisan non-fiksi dapat dipublikasikan dalam jurnal ilmiah, sementara bentuk tulisan dalam bentuk fiksi dapat dipublikasikan atau diajukan penerbitannya pada penerbit mayor yang memiliki jaringan distribusi buku diseluruh Indonesia, selain itu peserta juga diarahkan menerbitkan tulisan melalui penerbit minor yang memanfaat media jejaring sosial dan pola pertemanan, sehingga tulisan mampu dipublikasikan secara kreatif.

Secara aplikatif upaya mendorong kesadaran dunia literasi di kalangan pelajar, terkadang memiliki tantangan tersendiri, karena dengan perkembangan dunia teknologi semacam menghadirkan fenomena baru yakni semakin akrabnya para pelajar dengan gadget yang cenderung untuk sekadar hiburan dan bermain, ketimbang buku yang memberikan informasi dan pengetahuan, sehingga diperlukan sebuah cara baru dengan membawa gerakan literasi pada dunia digital, misalnya dengan penyediaan berbagai sumber bacaaan berbasis $e$-book, e-jurnal, website/blog komunitas, dan penggunaan media sosial saling bertukar infomasi. Oleh sebab itu, tantangan inilah yang harus dihadapi oleh semua pegiat literasi, tidak terkecuali para kader dan level pimpinan di lingkungan PD IPM Kabupaten Banyumas.

Hal yang dapat dilakukan oleh para kader dan pimpinan PD IPM Kabupaten Banyumas dalam jangka pendek yakni dengan mengoptimalkan media sosial oleh PD IPM Kabupaten Banyumas sebagai media publikasi dan berinteraksi dikarenakan tidak adanya sekat ruang dan waktu. Apalagi, dalam hasil pengamatan tim pelaksana kekeberadaan media sosial PD IPM Kabupaten Banyumas belum dikelola secara maksimal dan terencana, hal tersebut dapat terlihat dengan masih terencananya media publikasi dan tulisan kader PD IPM Kabupaten Banyumas yang bisa kita temui ada di blog www.ipmbannyumas.wordpress.com, sehingga dalam beberapa bagian perlu adanya perbaikan fitur dan update isi blog secara kontinyu yang berakibat pada konten isi blog yang hanya bersifat tentatif dan sekadar memenuhi agenda kerja periodesasi jabatan.

Adanya optimalisasi penggunaan media sosial oleh PD IPM Kabupaten Banyumas dikarenakan jumlah kader yang mampu mengakar kuat sampai 


\section{Islãmadîna \\ JURNAL PEMIKIRAN ISLAM}

tingkat ranting yang berbasis di sekolah.. Selain itu, berdasarkan hasil temuan Asosiasi Penyelenggara Jasa Internet Indonesia (APJII) menujukkan bahwa Kabupaten Banyumas menjadi kota kedua setelah Yogyakarta dalam hal penggunaan media sosial untuk kegiatan konsumtif. Hal tersebut terlihat pada pembelian pada jasa bisnis online yang didominasi oleh perempuan sebanyak $65 \%$ sedangkan sisanya 35\% laki-laki. (Radar Banyumas, 20 September 2015). Maka, hal inilah yang harus ditangkap oleh PD IPM Kabupaten Banyumas sebagai peluang untuk bisa dimanfaatkan sebagai media publikasi bentuk tulisan yang dihasilkan, baik dari kader atau pimpinan masing-masing level pimpinan PD IPM Kabupaten Banyumas. Potensi pengguna media sosial yang besar di Kabupaten Banyumas semacam memberikan banyak ruang untuk berkreativitas dan berekpresi bagi seluruh kader dan pimpinan PD IPM Kabupaten Banyumas, tidak saja dalam bentuk tulisan, melainkan juga digunakan mensosialisasikan bentuk dan rencana program yang ingin dilaksanakan dengan biaya dan cara yang cukup mudah.

Terlaksananya kegiatan pelatihan penulisan kreatif dan publikasi ini sebagai bagian dari upaya mendorong gerakan literasi bagi PD IPM Kabupaten Banyumas ini bermula dari hasil evaluasi pelatihan creative writhink (write and think) yang tim pelaksana dan mitra adakan beberapa bulan sebelumnya, sehingga adanya pelatihan ini merupakan tindak lanjut kegiatan sebelumnya tersebut. Pada saat berlangsungnya kegiatan pelatihan, para peserta memberikan respon positif dengan mengajukan pertanyaan dan tanggapan mengenai mengenai materi yang disampaika oleh pemateri, baik mengenai tulisan dan penulisan non-fiksi, fiksi, dan teknik publikasi. Bahkan terdapat peserta yang berbagi pengalaman terkait tulisan yang sudah tinggal publish, sehingga suasana forum menjadi sebuah forum diskusi dinamis disebabkan para peserta sudah memiliki pengalaman tentang tulis menulis.

Terjadinya hubungan dialogis-interaktif antar peserta dalam proses berlangsung pelatihan menyebabkan transfer pemahaman dan pengalaman terkait pentingnya gerakan literasi menjadi sangat mudah untuk dipahamai dan dimengerti antar sesama peserta, sehingga posisi pemateri hanya memberikan intrepretasi dan konstruksi bahwa gerakan literasi tidak bisa dipisahkan dari organisasi perkaderan, termasuk PD IPM Kabupaten Banyumas. Maka, upaya mendorong optimalisasi gerakan literasi para semua kader dan pimpinan pada semua level pimpinan harus senantiasa digelorakan dan digerakkan. Apalagi, secara ideologis keberadaan dunia literasi tidak dapat dipisahkan IPM, hal tersebut dikarenakan IPM secara gerakan sangat terinspirasi dari Ayat Al Qur'an "Nuun. Wal qalami wa maa yasturuun". Artinya, dunia literasi sebenarnya tidak 
bisa dipisahkan dengan ideologi dan gerakan IPM itu sendiri. Maka, adanya persamaan visi dan misi pada masing-masing kader dan pimpinan menjadi nadi keberhasilan optimalisasi gerakan literasi ditubuh IPM, khususnya pada PD IPM Kabupaten Banyumas.

Terkait hasil dari proses pelaksanaan kegiatan ini dapat tergambar dengan sebagaimana telah dijelaskan dalam luaran kegiatan ini, yakni: pertama, berdasarkan hasil evaluasi terhadap para peserta pasca sesi masing-masing materi mayoritas menunjukkan bahwa para peserta mendapatkan tambahan wawasan mengenai proses penulisn kreatif dan publikasi, sehingga harapannya pasca pelatihan senantiasa menjaga konsistensi membaca dan menulis yang pada akhirnya memperbesar skala gerakan literasi organisasi. Indikator keberhasilan kemampuan peserta untuk memahami, menyusun dan membuat karya dalam bentuk non-fiksi dan fiksi yang ditandai dengan menjelaskan dan memberikan contoh tulisan pada saat berlangsung pelangsungnya materi pelatihan. Kedua, para peserta dapat mempunyai kemampuan atau skill dalam untuk menulis non-fiksi dan fiksi secara kreatif, sehingga dapat dibuktikan dalam berbagai hasil karya yang dapat dipublikasikan secara baik dan dinikmati khalayak luas.

Hal tersebut didasarkan pada komitmen para peserta bahwa pasca sesi materi pelatihan yang berkeinginan untuk menulis karya tulisannya kedalam berbagai media publikasi. Setidaknya, hal tersebut mengoptimalkan media informasi dan Maos Corner (taman bacaan) PD IPM Kabupaten Banyumas. Ketiga, komitmen peserta untuk menjadi penulis non-fiksi atau fiksi yang dilakukan secara kreatif, hal ini ditandai dengan keseriusan PD IPM Banyumas dalam memfasilitasi penerbitan buku baik dicetak untuk kalangan internal atau melalui penerbit mayor yang sudah memiliki distributor tersendiri sehingga dapat diakses secara cepat dan luas. Selain itu, komitmen pimpinan PD IPM Kabupaten Banyumas juga memberikan akes terhadap para peserta untuk menerbitkan buku melalui penerbit minor (indie) yang skalanya cukup terbatas untuk akses penjualan, sekalipun tidak mengurangi makna dari upaya mendorong budaya menulis dan membaca di kalangan internal PD IPM Kabupaten Banyumas.

Peserta juga diberikan penjelasan mengenai keuntungan dan kelebihan menerbitkan buku para penerbit mayor dan penerbit minor, sehingga peserta bisa mendapatkan beragam pilihan yang sesuai dengan passion peserta sebagai seorang penulis. Oleh sebab itu, para peserta cukup antusias berdiskusi baik dengan para pemateri maupun dengan sesama peserta, sehingga secara keseluruhan pelaksanaan materi pelatihan menulis kreatif dan publikasi dalam upaya mendorong gerakan literasi pada PD IPM Kabupaten Banyumas berjalan 


\section{Islãmadîna \\ JURNAL PEMIKIRAN ISLAM}

secara lancar dengan harapan dapat mentransformasikan semua rangkaian kegiatan pelatihan pada internal organisasi dan pelajar secara umum di masing-masing asal sekolah para kader PD IPM Kabupaten Banyumas.

Tahap selanjutnya dari kegiatan ini adalah adanya bentuk tindak lanjut yang dapat dilaksanakan secara kolektif oleh PD IPM Kabupaten Banyumas. Sebab, beberapa hal-hal yang belum dibahas pada saat proses pelaksanaan pelatihan bisa dilakukan pada pelaksanaan tindak lanjut (follow up). Artinya, sebagaimana lazimnya organisasi perkaderan untuk melakukan tindak lanjut pasca pelatihan salah satunya dengan mendorong adanya pengumpulan tulisan secara kolektif dari semua level pimpinan dan kader dari tingkat ranting sampai daerah, sehingga proses dan kegiatan tulis menulis dan publikasi harus berjalan terus menerus sampai menjadi sebuah kebiasaan yang tidak saja melekat gerakan organisasi, melainkan juga kepada para kader di lingkungan PD IPM Kabupaten Banyumas. Maka, dari sinilah keberhasilan PD IPM Kabupaten Banyumas dapat mengukur tingkat keberhasilan dari optimalisasi gerakan literasi yang telah direncanakan dan dilaksanakan dapat berdampak positif terhadap kader, pimpinan, dan masyarakat secara luas.

Cara lain yang dapat dilakukan oleh PD IPM Kabupaten Banyumas dalam melalukan proses tindak lanjut dari proses pelatihan ini dengan memberikan syarat artikel atau makalah pada setiap jenis jenjang perkaderan formal dan khusus yang secara rutin dilakukan oleh PD IPM Kabupaten Banyumas. Tentu saja, semua syarat artikel dan makalah yang dijadikan syarat tersebut dibuatkan tema dengan beragam sub bab tertentu, sehingga para peserta dapat membuat format dan bentuk tulisan secara variatif, tanpa harus keluar dari tema yang sudah ditentukan sebelumnya.

Selanjutnya, tahap yang dapat dilaksanakan oleh PD IPM Kabupaten Banyumas dengan menyunting semua tulisan yang telah terkumpul dan mengeditnya agar menjadi satu kesatuan tulisan yang utuh, sehingga kumpulan tulisan tersebut dapat dipublikasikan dalam bentuk buku ontologi yang dapat menampung semua tulisan sepanjang masih ada kekesuaian dengan tema yang telah ditentukan sebelumnya. Selain itu, kumpulan tulisan yang tersedia tersebut dapat dipublikasikan secara rutin pada blog atau media sosial PD IPM Kabupaten Banyumas.

Sebab media daring cenderung lebih kreatif dalam mendorong kegiatan dalam berbagai pola, tidak terkecuali dalam gerakan gerakan filantropi sebagai fenomena unik baik nyata maupun maya yang mampu melokalisir gerakan tertentu secara maksimal (Makhrus, 2014: 34). Tentu saja, dalam konteks ini 
filantropi tersebut dapat berupa tulisan yang hasil publikasinya dapat digunakan untuk berdonasi.

Permasalahan dan hambatan yang harus dihadapi selama proses kegiatan ini lebih pada teknis pelaksanaan pelatihan, terutama penyesuaian jadual antara tim pelaksana dengan mitra dalam penentuan pelaksanaan kegiatan pelatihan. Hal tersebut dikarenakan kondisi mitra yang akan menjadi peserta pelatihan masih harus menyesuaikan dengan jadual kegiatan PD IPM Kabupaten Banyumas dan ujian tengah semester sekolah. Sehingga, rencana kegiatan pelatihan yang rencananya akan dilaksanakan pada tanggal telah ditentukan harus diundur dengan mengatur jadual kembali. Hal tersebut juga dipengaruhi oleh jadual tim pelaksana untuk menentukan waktu kegiatan pelatihan yang terkadang perlu penyesuaian jadual dengan kegiatan yang ada di Prodi. Selain itu, pada proses pelaksanaan kegiatan, hambatan lain yang dihadapi adalah keberadaan peserta yang sebagian tidak membawa hasil karya tulisannya baik dalam bentuk soft copy maupu hardcopy, sehingga berjalannya diskusi dalam masing-masing materi hanya diwakilkan peserta yang telah membawa tulisan disamping didasarkan hasil pengalaman para peserta yang telah menulis dan mempublikasikan tulisannya.

Harapan tim pelaksana dan mitra terhadap kegiatan ini agar kegiatan penulisan kreatif dan publikasi dalam mendorong gerakan literasi pada PD IPM Kabupaten Banyumas dapat dilaksanakan para organisasi pelajar dan pemuda yang lain, sehingga kesadaran dalam mendorong budaya literasi menjadi kegeliasan dan permasalahan bersama disemua organisasi pelajar, mahasiswa, kepemudaan, dan masyarakat. Apalagi, persoalan mendorong kesadaran membaca dan menulis tidak saja menjadi kewajiban satu organisasi saja, melainkan menjadi kewajiban kolektif oleh negara dan semua masyarakat, sehingga para generasi dimasa depan menjadi generasi cemerlang melek huruf dan berpengetahuan.

\section{SIMPULAN DAN SARAN}

Gerakan literasi PD IPM Kabupaten Banyumas secara padigmatik sudah menjadi visi ideologis gerakan yang secara kolektif dilaksanakan di tanah air. Sebab, keberadaan IPM yang basis gerakannya berada di tingkat pelajar memilki peranan penting dalam membina pelajar yang berkemajuan melalui nilai dasar-dasar sebagaimana dilakukan oleh semua organisasi otonom Muhammadiyah.dianggap visi paradigmatik sebab pentingnya gerakan literasi dapat terlihat dengan jargon IPM "Nuun. Wa qalami wa maa yasturun" yang diambil dari QS. ayat 1-2. Maka, adanya pelatihan penulisan kreatif dan 


\section{Islãmadîna \\ JURNAL PEMIKIRAN ISLAM}

publikasi merupakan salah satu dorongan untuk agar gerakan literasi PD IPM Kabupaten Banyumas dapat berjalan secara baik dan maksimal.

Berdasarkan pada proses kegiatan penulisan kreatif dan publikasi dalam mendorong gerakan literasi pada PD IPM Kabupaten Banyumas, menurut tim peneliti menghasilkan beberapa kesimpukan, yakni: pertama, gerakan literasi pada PD IPM Kabupaten Banyumas sudah berjalan dengan cukup baik, hal tersebut dapat terlihat dengan adanya Maos Corner sabagai sebuah perpustakaan mini yang dapat diakses oleh semua pihak, sehingga adanya pelatihan penulisan kreatif dan publikasi sebagai bagian dari tindak lanjut kegiatan tim pelaksana selenggarakan sebelumnya. Kedua, secara kolektif budaya dan kesadaran menulis sudah terbangun pada PD IPM Kabupaten Banyumas, hal tersebut ditandai dengan diterbitkannya buku "Tulis Terus Tulis Tulus Tulis Mulus" yang merupakan kumpulan tulisan dari kader PD IPM Kapupaten Banyumas, sehingga keberadan pelatihan penulisan dan publikasi ini sebagao upaya optimalisasi kegiatan tulis menulis agar semakin banyak karya atau bentuk tulisan yang dihasilkan dari para kader dan pimpinan PD IPM Kabupaten Banyumas.

Ketiga, dibutuhkannya upaya optimalisasi penggunaan media sosial untuk kebutuhan dan syiar gerakan oleh PD IPM Kabupaten Banyumas, sebab sementara ini media sosial yang menjadi sumber informasi dan berita utama dari PD IPM Kabupaten Banyumas yakni blog www.ipmbannyumas.wordpress.com.masih belum diperbaharui, baik secara konten dan kebaharuan isi. Upaya spesifik yang sudah dilaksanakan dan perlu ditingkatkan oleh PD IPM Kabupaten Banyumas dalam mendorong gerakan literasi adalah pemberian apressiasi terhadap para kader yang telah memiliki banyak naskah untuk segera diterbitkan atau yang sudah diterbitkan, hal tersebut ditandai dengan adanya forum diskusi dan bedah buku yang pernah dilaksanakan yang bersumber dari tulisan para kader, baik di internal PD IPM Kabupaten Banyumas sendiri maupun IPM secara kolektif nasional. Selain itu, penambahan literatur melalui donasi Maos Corner harus terus dilakukan secara kreatif dan inovatif, sehingga bahan refernsi menjadi lebih banyak.

Hal yang patut menjadi catatan dalam proses pelaksanaan kegiatan tersebut diaatas, terbagi atas beberapa bagian yakni: pertama, durasi waktu pelaksanaan, minimnya durasi waktu pelaksanaan kegiatan menyebabkan masih minimnya praktik yang dapat dilaksanakan sepanjang proses pelatihan, hal ini karenakan orientasi yang diharapkan oleh pihak mitra dalam menyelesaikan permasalahannya adalah pelatihan, bukan workshop yang dapat memberikan durasi waktu yang lebih panjang. Kedua, perlunya perluasan mitra, hal ini 
dikarenakan mitra dalam kegiatan ini hanya berasal dari organisasi saja, sehingga dampaknya kurang meluas dibanding dilaksanakan pada banyak organisasi 


\section{Islãmadìna \\ JURNAL PEMIKIRAN ISLAM}

Volume XVIII, No. 2, Juni 2017 : 57-74

\section{DAFTAR PUSTAKA}

Aries Musnandar. Beda Menulis Ilmiah dan Menulis Kreatif. Diakses http://old.uin-malang.ac.id/index.php?option=com_content\&view=a rticle\&id=3914: beda-menulis-ilmiah-dan-menulis-kreatif\&catid=35 :artikel\&Itemid=210 8/10/2015 waktu 07.39

Djibran Pahdepie. 2010. Menatap Punggung Muhammad. Jakarta: Litera. 2011. Creative Writhink. Makalah. Akademi Berbagi Bali . 2016. Creative Writhink. Makalah. LPIP UMP https://www.youtube.com/watch?v=wZR7PrxOE18 diakses 8/10/2015 waktu 07.15

Makhrus, M., and Putri Dwi Cahyani. "Pelatihan Creative Writhink Pada Ikatan Pelajar Muhammadiyah Kabupaten Banyumas." ISLAMADINA (2017): 41-56.

Makhrus, M. "Aktivisme Pemberdayaan Masyarakat Dan Institusionalisasi Filantropi Islam di Indonesia." ISLAMADINA (2014): 23-44.

Ostrom, Hans. "Undergraduate Creative Writing: The Unexamined Subject." Writing on the Edge 1.1 (1989): 55-64.

Dika, Raditya. 2014. Rahasia Menulis Kreatif. E-book.

Juleha, St. Peningkatan Kemampuan Menulis Kreatif Cerpen Siswa Kelas VIIIA SMPN Rambipuji Jember Melalui Strategi Sugesti Imajinasi. Jurnl Nosi, Volume 1 Nomor 4, Agustus 2013, hal. 351-360.

Komunitas Semangat Nuun. 2014. Tulis Terus Tulis Tulus Tulis Mulus. Purwokerto. Ilmi publisher

Tim Pusat Humas Kementerian Perdagangan RI. 2014. Panduan Optimalisasi Media Sosial untuk Kementerian Perdagangan RI. Jakarta: Kemendag RI.

www.ipmbannyumas.wordpress.com 